\title{
The Governance for the Knowledge Society: E-Government and Individual Freedom
}

\author{
Ligia Munteanu \\ Alexandru Ioan Cuza University of Iasi, Romania \\ Faculty of Economics and Business Administration
}

\begin{abstract}
The information seems to be the most important aspect of all sectors, including in economy and in governance. E-government is the new way of acting in the public administrative sector, at all levels, great for its aims and perspective, more dedicated to the citizens, working for them and with them. This paper acknowledges that individual knowledge is the most important element in the developing process of the society. The implementation of the e-government system should take into account all the problems encountered from previous systems with regards to state control, corruption, bureaucracy and limitation of individual freedom .
\end{abstract}

\section{Introduction}

In 1996, John Perry Barlow wrote on his on-line site of discussions:

"Governments of the industrial world, you weary giants of flesh and steel, I come from cyberspace, the new home of mind. On behalf of the future, I ask you of the past to leave us alone. You are not welcome among us. You have no sovereignty where we gather. ...You have not engaged in our great and gathering conversations, nor did you create the wealth of our marketplaces. You do not know our culture, our ethics, or the unwritten codes that already provide our society more order than could be obtained by any of your impositions.'"[2]

His words had an impressive impact in 1996, a time when Internet was "the best new, new thing" [16]. Since then government all around the world started to explore what kind of impact this "new, new thing" would have on their activity sector.

Along history, the economy passed through many ideologies and perspectives, depending on the needs of the time and on the new discoveries that changes everything. The world we live in today is not one "at the end of history" as Francis Fukuyama said, but more likely we are in a point of a new beginning.

As the information gains value and the communication becomes a primer asset all around the world, the essence of modern ways of doing business, we speak about the "knowledge based society" and "the new economy". In the middle of things stands the information, so the exchange of data between partners becomes essential to the development of the society.

\section{Literature Review}

The term of e-Government is of comparatively recent origin and even the oldest dedicated eGovernment policies and events only date from the late 1990s and early 2000s, mentioned for the first time in the Clinton Administration (1993-2000). However, the practice behind it is much older and goes back to the first, mainframe-centered wave of data processing in the public sector in the 1960s and 1970 s that frequently continues to shape existing information technology infrastructures. [11] These models were later use as experiments for the initiatives of present e-government systems.

One of the first e-government projects in America were The Cleveland Freenet, organized by Western Reserve University and The Public Electronic Network of the state Santa Monica, California. [5] In Europe, were implemented the Iperbole program and the Amsterdam's Digital City.[5] As well Great Brittan was one of the leaders in research in this domain since 1944, wanting a decrease of governmental costs and for a closer bond between citizens and governmental institutions.

The computers are becoming a common feature of the internal and exterior aspect of society and governments are slowly realizing that ICT, the Internet and the Web may have potential for the running of government, government departments and the public sector. 'E-government' is a term that has been circulating in Information Technology (IT) and government circles for some time. At the third Annual E-government Conference held in Lisbon during May 2002, the term 'e-government' was used in the following way:

"E-government is the application of Information and Communication Technology by government and 
public sector agencies, and is transforming the way governments interact with their citizens. Its use promises to enhance the effectiveness and efficiency of government and radically alter its relationship with the public. Improvements in communication and technology are playing a vital role in raising the living standards and empowering people to understand and gain access to all the initiatives and support systems that are available to them. "[10]

To this definition we can add the goals of egovernment, as formulated by the World Bank [22]:

- governmental services more efficient and more fast for the citizens;

- better relation with the firms and industry;

- more efficient governmental management;

- $\quad$ increasing transparency in public decisions;

- decrease of corruption;

- decrease of costs in the public administrative sector;

- participation of individuals in the governmental act.

So the attributes of e-government are: faster, more efficient, more transparent in order to change the governmental system approach in one that is closer to the citizens, for them and with them.

\section{Data Management in E-government}

The whole governmental activity depends on the information collected from the citizens. The taxes are calculated taking into consideration the incomes of individuals, their certified properties and location, urban or rural. Because data is the vital resource of any administrative system, it is important that it has a strategic organization, for a good manipulation of information according to the European Directive 95/46/EC that states rules regarding the protection of citizens in the process of organizing personal data. The directive is structured around 5 pillars: information interpretation, collecting and storage of data, information management, electronic data exchange, safety and security of data. [23]

The information obtained in the administrative process must be transformed as to represent reality. Many times data collection is not a perfect operation, since not every citizen responds in the same way to the administrative call. Still the statistics must keep the regional characteristics. The data will suffer changes in their way to form a conclusion for the governors, but if these changes are affecting the structure of the data, it means the reality is distorted.

Another aspect is the time. The data may refer to a specific point in time or to a period. E-government promises a higher degree of accessibility to information for the citizens, meaning that all these resources should be certified, clear and in correlation with the temporal units used.
E-government as a whole system starts from data collection, each action having a certain purpose, observed carefully by specialized structures that know also the final objective that those information will get. The collection is made once, as closer to the source as possible, with direct and crystal clear questions. The information are collected, analyzed and stored accordingly to their meaning. After this process of initial filtering, the information becomes useful data. The packages of new data, after a validation, become the resource for governmental planning. Also, a part of the obtained statistics are given for public use in an organized and simplified form, easy to access and use.

Because all these actions are made on the Internet, on electronic devices and in a virtual medium, the problem of security is not a simple one. Many questions arise about how should an institution be sure about authenticity of data and how could the system be protected and secured. Of course these is still a weak point for the e-government, because any new technology finds new hackers, but the future will bring solution to these problems. A system of monitoring may be a powerful guardian of data channels and also keeping duplicates of every transaction and log-ins.

The confidentiality is another aspect to be considered. As people act behind a computer, there is a high risk of using another identity. Virtual signature and electronic identity cards came as a guaranty for identification. The key here is not always a new technology, but the possibility of quick announcements in case of fraud.

The security aspect should cover two aspects: the data and the system itself. The best method of protection is initial prevention. The policies of safety for e-government systems ask for a proper legislation. Though is it difficult for the law to keep up with technological progress, general laws must be written, covering up as many aspects of the process. The right implementation of the next generation for administrative programs calls for an active justice, prepared for unpredicted actions.

The European Union has brought some of the best security policies regarding informational data management, since the beginnings of e-government:

- Directive 95/46/EC regarding the protection for citizens in transfers of personal data;

- Directive 97/66/EC regarding personal data management and protection for private space in telecommunication sector;

- Directive 1999/93/EC on community infrastructure of electronic signatures;

- Directive 2000/31/EC on legal aspects of delivering informational services to the society;

- Directive 2002/58/EC on protection of personal data and private space in electronic communications.[23] 
As good as these directives may be, there is still a question to be asked. Could there be possible to have a private space in the virtual world? From a point of view the answer could be negative thinking that behind any program stand people that manage the system and human nature will always be under the sign of uncertainty. On the other hand, the world of the Internet is so complex now, it has reached a level only dreamed some years ago and comes as a value physical life can't be without. So if every aspect of the society will be transformed in the virtual world, the risks taken there will not be as different as in the real life. In the end, who has not been a victim of a simply thief?

\section{Individual Freedom in E-government}

Individual freedom means the possibility of one person to live free, in a private space, in coordination with the general rules of society and along history was associated with the less governmental implication.

The intervention of the government in the economy is measured by Economic Free World Index (EFW) and Index of Economic Freedom. Both came with the conclusion that economic liberty is correlated with economic growth and that more free countries are the ones that have the biggest number of computers connected to Internet.

The technologic progress is considered a determinant factor for economic growth, but in this knowledge based society, where the global economy tends to capture everything, the question is if the form of knowledge and technologic explosion corresponds to the freedom of the individual.

The values of individual freedom, human rights and fundamental liberties are stonlgly sustained by all democtacies today, the states ordered by the rule of law and it is interesting to see how in the informational era, the role of government implication seems to come to the same point as it did for centirues. Guvernmental prezence in citizens live was many times argued by the need of protecting the citizzens and the market, and the protection meens more and more regulation.

In the virtual world, the motivation of ,protecting the citizens and the companies in the network", seems to be the same excuse, but just put in a different context. The principles of democracy must be right implemented in the virtual space, or we will just come in few ears to speak of birocracy, lake of transparency and coruption, duffering only from the e- infront of the words (e-birocracy, e-coruption,etc).

E-government aims to reduce the barriers of communication, better governmental services, efficient collaborations between institutions, and very important better relation with the business sector. But all these depend on the degree of integration of the administrative levels of organization and access to information. The main problems are those of insufficient development of infrastructure, the absence of a proper legal framework, access tariffs.

In 2003, at the World Summit on Informational Society, Romania was awarded with the prize "best digital content" for the e-government system, but even today, after many years, the Romanian citizens cannot benefit from this system. The lack of development in the rural regions shows that in half of the country's population are people without any computer or Internet possibilities. From this it is natural to observe that the percents of using the egovernment system are far away from the European results.

The knowledge based society it is hoped to be a free knowledge based society. The knowledge is aimed to be the resaoult of the individual abilities, of permanent feed-back and communication. This process remindes of the spontaneos order of Hayek, where singular individuals, through attempts and errors can descover new things and make more efficient some processes, without any outside intervention. The difference is that today, all this scenarium is on the net.

Peter Steiner was remarcable when he said: "On the Internet, nobody knows you're a dog”. It seems possible, that on the Internet, the information, the messages, the data can be transmitted in an anonymous way, or dissimulating some appearance. A society, that doesn't recognize that each individual has its own value that he must follow, can't have any respect for the dignity of the individual and can't know the right meaning of freedom. [14]

In a free knowledge based society human rights are upon the control and concentration of power. Each person has the right to interact free and not to be the subject of others or institutions control. Free knowledge means that individuals are upon institutions. The limitation of the disseminated knowledge must be justified, because the rule is the freedom and the control must be only the exception with a derogation character. Free knowledge means that individuals have their own mental maps and they decide what connections they make and what they need from the information they have.

Free knowledge means the belief in the invisible hand of Adam Smith, producing spontaneously the way for economic growth and the key to the development of the complex society we live in today.

\section{Conclusions}

The world is changing with amazing speed and there are things accomplished today that our grandfathers not even dreamed of. But still, one subject cannot be forgotten and still rises questions, the individual freedom. This is an aspect with 
implications in all domains, being the motivation for wars, fights and dreams of all people through time.

E-government brings great advantages and it will be a big step in the history of governmental policies, bringing this system to its original goal: to be for the people, by the people and with the people. It will redirect the governmental actions to the needs of individuals and bring strong advantages in the business sector.

The reform of e-government will be made in several steps. At first, the system will need people working in the administrative public sector to know how to deal with the application, how to use it, how to collect the data and the guidance through the process until the data is transformed and delivered back to the people. After this, it is necessary to speak about a better communication between local administrative levels and governmental ones. Very important is the education of the citizen, to use the system, to trust it, to cooperate in a proper way.

But even if technology is important and changes our life in a way never seen before, the most important element of the society remains the individual. His freedom must be well protected and the free market is a dream of the economists that must become a reality as soon as possible.

E-government brings as well new forms of trusting that the knowledge based society is a free one, but also have the means that can lead to exeded governmental control.

As Karl Popper said: „The pfenomena of human knowledge is, undoubtly, the geatest miracle of our univers and as well a problem that will not be solved soon " [15].

The knowledge doesn't exist but under the form of indivudual knowledge. To speak about knowledge of a society as a hole, is nothing more that a beautifull, but empty, methaphor...

\section{References}

[1] Access Conferences, (2002), Global Summit for MultiChannel e-Government and e-Public Services, Paper presented at the Global Summit for Multi-Channel eGovernment and e-Public Services, Lisbon, Portugal.

[2] Barlow, J. P. (1996), The Declaration of the Independence of Cyberspace

http://www.eff.org/ barlow/Declaration-Final.html (Access Date: December 08. 2009).

[3] Bennett, W., Lance., and Entman, Robert, M., (Ed.). (2001). Mediated Politics: Communication in the Future of Democracy, New York: Cambridge University Press.

[4] Bozeman, B. (2000),Bureaucracy and Red Tape, Upper Saddle River, NJ:Prentice Hall.

[5] Castells, M. (2001), The Internet galaxy: reflections on the Internet, business, and society, Oxford; New York: Oxford University Press.

[6] Chen, Y.N., Chen, H.M., Huang, W. şi Ching, R.K.H. (2006), E-Government Strategies in Developed and Developing Countries: An Implementation Framework and Case Study, Journal of Global Information Management, Vol.14, p. 23.

[7] Coleman, S., Taylor, John., and van de Donk, Wim (Ed.), (1999), Parliament in the Age of the Internet, Oxford; New York: Oxford University Press.

[8] Costas, V., Lepouras, G., Fraser, J. şi Georgiatis, P. (2005), Barriers to Electronic Service Development, E-Service Journal, Vol. 4, p. 41.

[9] Dunleavy, P., Margetts, H., Bastow, S. and Tinkler, J. (2005), New Public Management Is Dead - Long Live Digital - Era Governance, Journal of Public Administration Research and Theory.

[10] European Commission (2006), i2010 eGovernment Action Plan: Accelerating eGovernment in Europe for the Benefit of All, Communication From the Commission to the Council, the European Parliament, the European Economic and Social Committee and the Committee of the Regions, Brussels, $\operatorname{COM(2006)} 173$ final. http://ec.europa.eu/information_society/activities/ego vernment/docs/highlights/comm_pdf_com_2006_01 73_f_en_acte.pdf (Access Date: December 09. $2009)$

[11] European Committee for Standardization (CEN) (2008), Final Report of the CEN/ISSS eGovernment Focus Group on the eGovernment Standards Roadmap, Eds. Marc Wilhelm Küster M.W., Dekkers, M., Moore G.

http://www.cen.eu/CENORM/sectors/sectors/isss/act ivity/finalreport1.pdf (Access Date: December 07. 2009).

[12] Fukuyama F., (1993), The End of Hsitory and The Last Man, Harper Perennial (February 1, 1993).

[13] Grönlund, A. (Ed.). (2002), Electronic Government: Design, Applications and Managemen, London; Hershey: Idea Group Publishing.

[14] Hayek, F.A. (2006), The Constitution of Liberty, University Of Chicago Press; Pbk. Ed edition (October 15, 1978).

[15] Karl Popper (1992), Objective Knowledge - An Evolutionary Approach, Clarendon Press, Oxford. 
[16] Lewis, M. (2000), The new new thing : a Silicon Valley story. New York; London: W. W.Norton.

[17] Mises, L. (1962),Birocraţia, New York.

[18] Stahi, B, E-Government and the Transformation of Bureaucracies: Some remarks about the Development of a Customer-Centred Information Society in Ireland, De Montfort University, Faculty of computer Science and Engineering.

[19] Stiglitz, J., Orszag, P. and Orszag, J. (2000). The role of government in a digital age, Computer \& Communications Industry Association.

[20]Towner Phelan,(2010), Reactionary Liberals, in Mises Daily.

[21] Weber, M. (1968), Economy and Society, Conceptual Exposition, Vol. 1, pp. 956-1005.

[22] http://www.worldbank.org/publicsector/ egov/ (Access Date: December 05.2009).

[23] http://europa.eu.int/comm/internal_market/ en/ dataprot/ law/ index.html

(Access Date: January 24.2011) 